\title{
Effect of Inoculation with Three Phytohormone Producers Phytobacteria with ACC Deaminase Activity on Root Length of Lens esculenta Seedlings
}

\author{
Natalia Elenes Zazueta ${ }^{1}$, Orlando Ortega Acosta ${ }^{2}$, Laura Martínez Herrera ${ }^{2}$, Raúl Alcalde Vázquez ${ }^{2}$, \\ Eugenia López López ${ }^{2}$, Angelica Guerrero Zúñiga ${ }^{3}$, Angelica Rodríguez Dorantes ${ }^{2 *}$ \\ ${ }^{1}$ Advanced Technological Institute of Cajeme, Sonora, México; ${ }^{2}$ National School of Biological Sciences, I.P.N., México City, \\ México; ${ }^{3}$ Mexican Petroleum Institute, México City, México. \\ Email: ${ }^{*}$ rodorantes@yahoo.com.mx
}

Received September 21 $1^{\text {st }}, 2013$; revised October $20^{\text {th }}, 2013$; revised October $27^{\text {th }}, 2013$

Copyright (C) 2013 Natalia Elenes Zazueta et al. This is an open access article distributed under the Creative Commons Attribution License, which permits unrestricted use, distribution, and reproduction in any medium, provided the original work is properly cited.

\begin{abstract}
Plant-associated bacteria that inhabit the rhizosphere may influence the plant growth by their contribution to the endogenous pool of phytohormones and by the activity of ACC deaminase to decrease the ethylene concentration. The aim of this study was to analyse the root length growth by the promoting effect of indole acetic acid producers phytobacteria with ACC deaminase activity, on inoculated seeds of Lens esculenta as synergistic effect on root elongation. In this study, although the roots of $L$. esculenta seedlings do not show a significant promotion, these phytobacteria could be recommended to treat plants analyzing their added inoculum to increase plant biomass and retard the effect of ethylene on cultures supplied with Tryptophan and ACC.
\end{abstract}

Keywords: Plant Growth-Promoting Bacteria; Lens esculenta; Root Elongation Test; Indole Acetic Acid; ACC Deaminase Activity

\section{Introduction}

The 1-aminocyclopropane-1-carboxylate (ACC) deaminase (ACC deaminase) hydrolyses the 1-aminocyclopropane-1-carboxylate (ACC) into ammonia and $\alpha$-ketobutyrate instead of its conversion into ethylene; the uptake and cleavage of ACC by this enzyme decrease its amount and as consequence the ethylene concentration in plants [1-5]. Authors reported that the ACC deaminase trait has been extensively studied in numerous soil microorganisms, but it is most common among plant growth promoting rhizobacteria to protect plants from both biotic and abiotic stresses and favor the increase of plant biomass through the regulation of ethylene synthesis in inoculated plants [5-14]. Bacteria that inhabit the rhizosphere also may influence the plant growth by their contribution to the endogenous pool of phytohormones, such as auxins in plants; the production of the auxin Indole Acetic Acid (IAA) is reported among plant-associated bacteria [15]. The aim of this study was to analyze the

"Corresponding author. root length growth by the promoting effect of indole acetic acid producers phytobacteria with ACC deaminase activity on inoculated seeds of Lens esculenta as synergistic effect on root elongation.

\section{Materials and Methods}

\subsection{Evaluation of the IAA Production of the Selected Phytobacteria}

The phytobacteria employed: Lemna 2 strain, U-M1-4 strain and U-M1-5 strain, were isolated from the aquatic plant Lemna gibba, collected from the Lake Xochimilco, México. The selected phytobacteria were analyzed by their Indole Acetic Acid (IAA) production [16,17] using the Salkowski reagent according to the method of Bric et al. [18] and Melo et al. [19], taking $4.9 \mathrm{~mL}$ of sterile Luria-Bertani (LB) liquid media, added to culture tubes $(10 \times 15 \mathrm{~cm})$; the culture tubes were inoculated with 0.1 $\mathrm{mL}$ of each phytobacteria with an adjusted inoculum by optical density of $5 \times 10^{7}$ cells $/ \mathrm{mL}$ in sterile distilled water and incubated at $28^{\circ} \mathrm{C}$ for $120 \mathrm{~h}$. After the incubation, 
the cultures were centrifuged at $3,500 \mathrm{rpm}$, at $25^{\circ} \mathrm{C}$ for 45 minutes to discard the bacteria pellets, the supernatant was recovered and $2 \mathrm{~mL}$ of each supernatants were mixed with $2 \mathrm{~mL}$ of Salkowski's coloring reagent, the development of a pink color indicates IAA production and was quantified reading its absorbance at $535 \mathrm{~nm}$. The concentration of IAA was estimated by a standard curve and the assays were performed by triplicate.

Evaluation of the ACC deaminase activity of the selected phytobacteria The ACC deaminase activity of the isolates was assayed according to the method of Penrose and Glick [20] and Khandelwal and Sindhu [21], with $\mathrm{ACC}$ and $\left(\mathrm{NH}_{4}\right)_{2} \mathrm{SO}_{4}$ as sole nitrogen source. The assay was done using agar plates with DF minimal medium [22] supplemented with ACC $(1 \mathrm{mM})$ or $\left(\mathrm{NH}_{4}\right)_{2} \mathrm{SO}_{4}(2 \mathrm{~g} / \mathrm{L})$, equally divided into 24 sectors and spot inoculated with a sterile toothpick each colony of the selected phytobacteria. The plates were incubated at $28^{\circ} \mathrm{C}$ for 48 to $72 \mathrm{~h}$ and the presence of ACC deaminase activity, was recorded by the measurement of the diameter of the colonies and compared between the two nitrogen conditions. The assays were performed by duplicate.

\subsection{Effect on Root Growth of Lens esculenta Seedlings Inoculated with the Selected IAA Producers with ACC Deaminase Activity Phytobacteria}

Bacterial inoculum were obtained by culturing the phytobacteria strains on plates with LB agar medium for $48 \mathrm{~h}$ at $28^{\circ} \mathrm{C}$ and re-suspending in sterile distilled water to adjust by optical density an inoculum with cell density of $5 \times 10^{7}$ cells $/ \mathrm{mL} ; 0.1 \mathrm{~mL}$ of the bacterial suspensions were spread on Petri dishes containing mineral medium with phytagel, added with Tryptophan $(2 \mathrm{mg} / \mathrm{L})$ and/or ACC $(1 \mathrm{mM})$. The plates were stand for 30 minutes for the inoculum absorption. Twenty five commercially seeds of Lens esculenta were surface-sterilized with $10 \%$ sodium hypochlorite and then thoroughly rinsed with sterile distilled water and placed in the Petri dishes, with the respective conditions. Petri dishes with mineral medium containing: $0.20 \mathrm{M} \mathrm{NH}_{4} \mathrm{H}_{2} \mathrm{PO}_{4}, 0.50 \mathrm{M} \mathrm{NH}_{4} \mathrm{NO}_{3}$, $1.15 \mathrm{M} \mathrm{Ca}\left(\mathrm{NO}_{3}\right)_{2}, 0.26 \mathrm{M} \mathrm{CaCl}_{2}, 0.2 \mathrm{M} \mathrm{MgCl}_{2} \cdot 6 \mathrm{H}_{2} \mathrm{O}$, $0.20 \mathrm{M} \mathrm{Mg}\left(\mathrm{NO}_{3}\right)_{2} \cdot 6 \mathrm{H}_{2} \mathrm{O}, 0.40 \mathrm{M} \mathrm{MgSO}_{4} \cdot 7 \mathrm{H}_{2} \mathrm{O}, 0.20 \mathrm{M}$ $\mathrm{KH}_{2} \mathrm{PO}_{4}, \quad 1.2 \quad \mathrm{M} \quad \mathrm{KNO}_{3}, \quad 0.5 \quad \mathrm{M} \quad \mathrm{K}_{2} \mathrm{SO}_{4}, \quad 0.04 \quad \mathrm{M}$ $\mathrm{FeCl}_{3} \cdot 6 \mathrm{H}_{2} \mathrm{O}, 1.2 \times 10^{-2} \mathrm{M} \mathrm{H}_{3} \mathrm{BO}_{3}, 1.2 \times 10^{-4} \mathrm{M}$ $\mathrm{CuCl}_{2} \cdot \mathrm{H}_{2} \mathrm{O}, 2.3 \times 10^{-3} \mathrm{M} \mathrm{ZnCl}, 4.4 \times 10^{-4} \mathrm{M}$ $\mathrm{MnCl}_{2} \cdot 4 \mathrm{H}_{2} \mathrm{O}, 6 \times 10^{-6} \mathrm{M} \mathrm{Na}_{2} \mathrm{MoO}_{4} \cdot \mathrm{H}_{2} \mathrm{O}$, EDTA and $\mathrm{FeSO}_{4} \cdot 7 \mathrm{H}_{2} \mathrm{O}, \mathrm{pH}= \pm 6.0$, and $3 \mathrm{~g}$ of phytagel; uninoculated treatments were considered as blanks. All the experiments were performed by duplicate and maintained at $30{ }^{\circ} \mathrm{C}$ in a growth chamber in dark for 4 days. The plant root elongation promoting (PREP) activity assay was employed to analyze the promoting and synergistic effect of rhizobacteria strains on Lens esculenta seeds, according to the modified root elongation assay of Belimov et al. [23], the root length of the seedlings were measure and the Growth Index (GI), expressed as the ratio of the root lengths of plants grown in the presence and absence of the phytobacteria, was obtained [14]; GI $=\mathrm{RLpb} / \mathrm{RLc}$, where RLpb is the root length of plants grown in the presence of the specific phytobacteria inoculum and RLc is the root length of plants grown in absence of inoculum (control).

\subsection{Statistical Analysis}

All data were analysed by One-way ANOVA analysis of variance and the mean differences were compared applying a Tukey-Kramer post-test, using the statistics program Graph Pad Instat Ver. 3.10.

\section{Results}

\subsection{IAA Production and ACC Deaminase Activity by the Tested Strains}

Lemna 2 strain and U-M1-4 strain presented a higher ACC deaminase activity $(\mathrm{p}<0.001)$ than U-M1-5 strain, according to their colonial diameter (Figure 1). The employ in the metabolic assay of ammonium sulfate as nitrogen source, was only taking it as control, compared to the ACC assay, but in this study, the two phytobacteria mentioned had a minor colony diameter, compared to the ACC activity. The three phytobacteria presented an increase in the IAA production as the tryptophan supply in cultures increased, the basal production of this auxin without the aminoacid presented this order: U-M1-5 strain $(32.67 \mu \mathrm{g} / \mathrm{mL})>\mathrm{U}-\mathrm{M} 1-4$ strain $(30.7 \mu \mathrm{g} / \mathrm{mL})>$ Lemna 2 strain $(19.32 \mu \mathrm{g} / \mathrm{mL})$, all the bacterial isolates were classified according to Khalid et al. [24] as higher phytohormone producers (Figure 2).

\subsection{Root Elongation Test of $L$. esculenta and the Effect of Phytobacteria Inoculation}

The response of $L$. esculenta roots showed that this species was susceptible to the presence of Trp, ACC and Trp + ACC, with a significant reduction on the root development compared to the roots grown on mineral medium: U-M1-4 strain 55\% > U-M1-5 strain 36.17\% > Lemna 2 strain $27.95 \%(\mathrm{p}<0.001)$. In general, inoculation with the three phytobacteria strains decrease the root length compared to the control roots (U-M1-4 strain > U-M1-5 strain > Lemna 2 strain). Particularly, the effect of the seeds inoculated with the strains and Trp showed that the order of response was as follows: U-M1-5 strain > U-M1-4 strain > Lemna 2 strain), the inoculated seeds and ACC: Lemna 2 strain > UM1-5 strain > UM1-4 and 

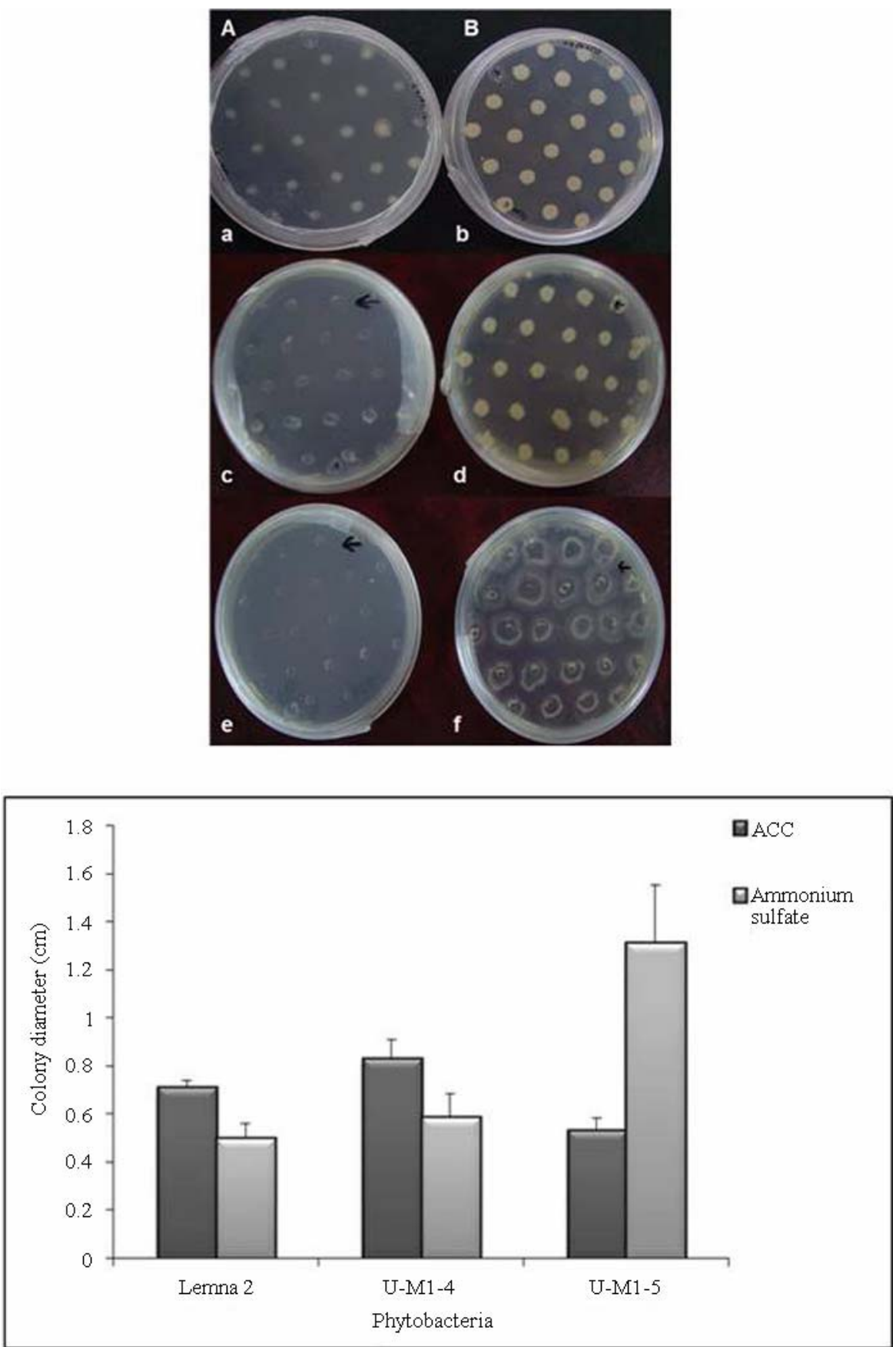

Figure 1. ACC deaminase activity of the phytobacteria tested: (A) DF minimal medium with ACC and (B) DF minimal medium with Ammonium Sulfate, where: “a and b" Lemna 2 strain, “c and d" U-M1-5 strain, “e and f” U-M1-6 strain. Mean values \pm S.D. from 48 replicates.

the inoculated seeds and Trp + ACC: UM1-5 strain > Lemna 2 strain > U-M1-4 strain (Figures 3 and 4).

\section{Discussion}

Glick et al. [25] showed that the promotion of root growth is one of the principal markers by which the beneficial effect of plant growth-promoting bacteria is measured. It is known from application of exogenous IAA [26] or application of diluted culture extracts or low density inoculum of bacteria that produce high levels of IAA $[27,28]$ that low concentrations of IAA can stimulate primary root elongation; it is important to note that the effect of bacterial IAA on plant growth depends on the size of the inoculum of a single strain, but not always, 


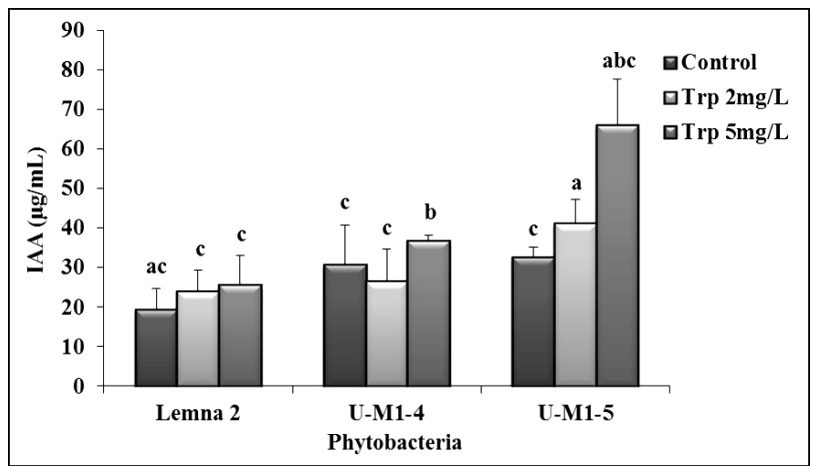

Figure 2. IAA in vitro production of the phytobacteria tested. Mean values \pm S.D. from three replicates.

the inoculum density employed means that more IAA is available to the plant, and reports of bacterial mutants that overproduce IAA show a root growth-inhibiting effect [29-31]. Burd et al. [14] and Belimov et al. [32] reported that there is a number of plant growth promoting bacteria that contain the enzyme ACC deaminase and stimulate the root growth of different plant species; ACC is exuded from roots or seeds and cleaved by ACC deaminase to $\mathrm{NH} 3$ and a-ketobutyrate, the bacteria utilize the $\mathrm{NH}_{3}$ as a source of nitrogen and thereby decrease ACC within the plant $[9,33]$ with the concomitant reduction of plant ethylene $[4,14,34,35]$. Patten and Glick [36] demonstrated that the IAA secreted by a bacterium may promote root growth directly by stimulating plant cell elongation or cell division or indirectly by influencing bacterial ACC deaminase activity. The authors mention that the IAA and ACC deaminase work together to stimulate the root elongation; this consideration is regarding to the exogenous IAA that increase the transcription and activity of ACC synthase; this enzyme catalyzes the production of $\mathrm{ACC}$ in plants and therefore ACC stimulates the ACC deaminase activity in bacteria [6,37], while the IAA produced by the bacterial inoculum, stimulates the root elongation or the formation of lateral and adventitious roots [29-31,38]. In this study, the correlation between the IAA production and the ACC deaminase activity by the phytobacteria tested, showed a relationship between the U-M1-4 and U-M1-5 strains that were joined together as one group by this attribute, separated to the Lemna 2 strain; probably the density of the inoculum produced a high IAA concentration that generated a inhibiting effect on root growth, joined to the ACC metabolism activity presented by the phytobacteria. This attribution is related with the visible short and thick appearance of the roots showed in the treatments with ACC and Trp + ACC. The effect of the inoculation with these three phytobacteria strains on Lens esculenta seeds, doesn't show an evident increase in the root length of seedlings; but particularly was the response of two of the isolates: Lemna 2 strain and

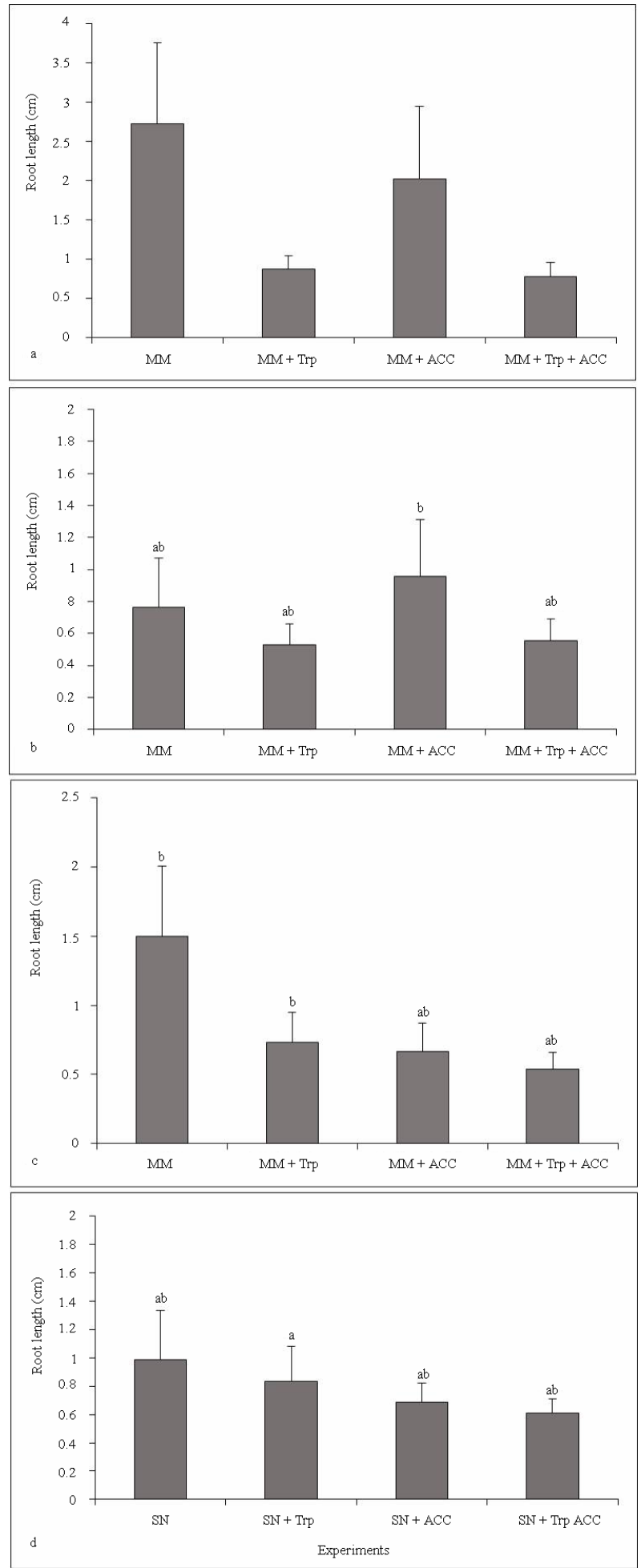

Figure 3. Root length measurement of Lens esculenta seedlings: (a) Control experiments, (b) Trp, ACC and Trp + ACC inoculated with Lemna 2 strain, (c) Trp, ACC and Trp + ACC inoculated with U-M1-4 strain and (d) Trp, ACC and Trp + ACC inoculated with U-M1-5 strain. Mean values \pm S.D. from 50 replicates, the different bold letters show the significant differences between experiments $(p<0.001)$. 


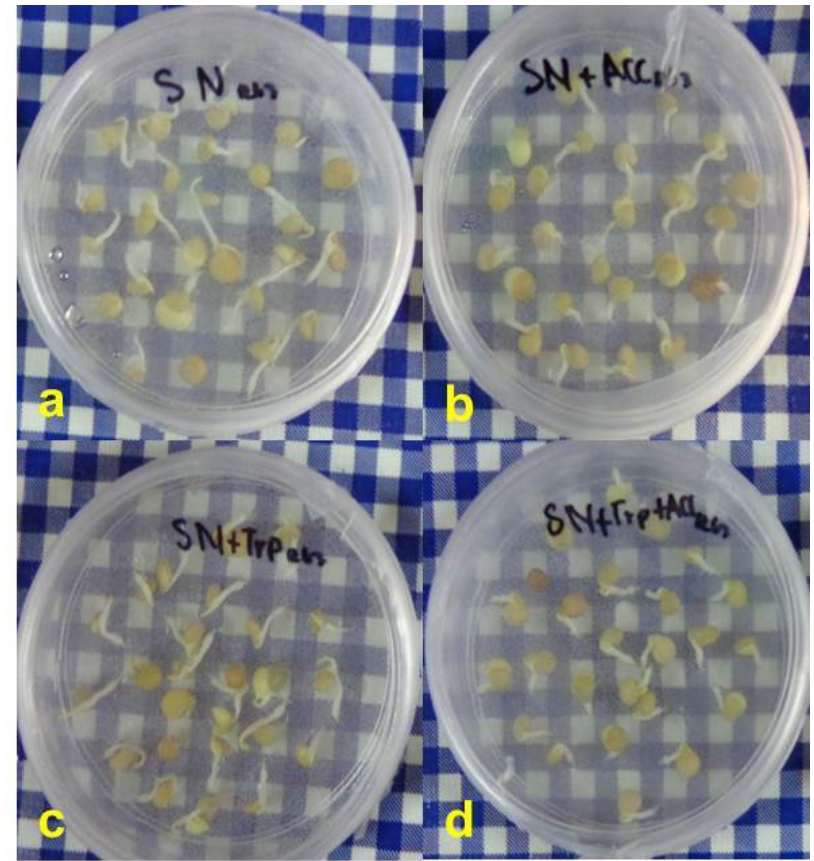

Figure 4. Root length experiments of Lens esculenta seeds inoculated with U-M1-5 strain: (a) Mineral Medium, (b) Mineral Medium + ACC, (c) Mineral Medium + Trp and (d) Mineral Medium + Trp + ACC.

U-M1-5 strain with a relationship according to their measured attributes: Lemna 2 strain with a high ACC activity (with a $47.32 \%$ of root growth compared to the control roots) and U-M1-5 strain with the highest in vitro IAA production (with a $94.98 \%$ of root growth compared to the control roots) especially with the presence of Trp $(2 \mathrm{mg} / \mathrm{L})$. Even the root length of the seedlings was lesser than control seedlings for both strains; the seeds' treatment with Trp + ACC showed that the response of the root length was higher in the experiments with TRP with U-M1-5 strain (with a $78.26 \%$ of root growth compared to the control roots) than Lemna 2 strain (with a $71.09 \%$ of root growth compared to the control roots).

These results were according to the results obtained by Zafar-Ul-Hye et al. [39]; these authors screened rhizobacteria containing ACC deaminase to promote lentil growth under axenic conditions and by Shaharoona et al. [5], who analyzed different strains of rhizobacteria with variations in their ACC deaminase activity, capability of the rhizobacterial isolates of IAA production in the presence and absence of tryptophane and isolates also varied in their ability to colonize etiolated pea roots; both according to the reports by Shaharoona et al. [40] and Zafar-Ul-Hye et al. [39] where the bacteria with more ACC deaminase activity had more ability to decrease the intensity of the called "ACC-induced classical triple response", the ACC deaminase activity of bacteria was responsible for the decrease of endogenous and exoge- nous ACC supply in inoculated plant with the inhibition on the root length of L. esculenta seedlings (Lemna 2 strain to the control roots). Finally, although the roots of L. esculenta seedlings do not show a significant promotion with the presence of the strains, Trp and ACC in medium; and even though these responses were adverse, the results obtained in this work suggested a synergistic effect between the two bacterial attributes probed and the phytobacteria tested and could recommended that it is important to consider the inoculum density to the increase of plant biomass and retard the effect of ethylene on cultures supplied with Tryptophan and ACC.

\section{Acknowledgements}

Authors are grateful to the Research Projects: SIP: 20131494 of the Secretaría de Investigación y Posgrado del I.P.N. and ISITDF/325/11 AREAS PRIORITARIASIPN and COFAA-IPN, EDI-IPN, SNI-CONACYT fellowships.

\section{REFERENCES}

[1] B. R. Glick, C. B. Jacobson, M. M. K. Schwarze and J. J. Pasternak, "1-Aminocyclopropane-1-carboxylic Acid Deaminase Plays a Role in Plant Growth Promotion by Pseudomonas putida GR12-2," In: M. H. Ryder, P. M. Stephens and G. D. Bowen, Eds., Improving Plant Productivity with Rhizosphere Bacteria, CSIRO, Adelaide, 1994, pp. 150-152.

[2] B. R. Glick, C. B. Jacobson, M. M. K. Schwarze and J. J. Pasternak, "1-Aminocyclopropane-1-carboxylic Acid Deaminase Mutants of the Plant Growth Promoting Rhizobacteria Pseudomonas putida GR12-2 Do Not Stimulate Canola Root Elongation," Canadian Journal of Microbiology, Vol. 40, No. 11, 1994, pp. 911-915.

http://dx.doi.org/10.1139/m94-146

[3] B. R. Glick, D. M. Penrose and J. Li, "A Model for the Lowering of Plant Ethylene Concentrations by Plant Growth-Promoting Bacteria," Journal of Theoretical Biology, Vol. 190, No. 1, 1998, pp. 3-68. http://dx.doi.org/10.1006/jtbi.1997.0532

[4] S. Mayak, T. Tivosh and B. R. Glick, "Effect of Wild Type and Mutant Plant Growth Promoting Rhizobacteria on the Rooting of Mung Been Cuttings," Journal of Plant Growth Regulation, Vol. 18, No. 2, 1999, pp. 49-53. http://dx.doi.org/10.1007/PL00007047

[5] B. Shaharoona, M. Arshad and Z. A. Zahir, "Effect of Plant Growth Promoting Rhizobacteria Containing ACCDeaminase on Maize (Zea mays L.) Growth under Axenic Conditions and on Nodulation in Mung Bean (Vigna radiata L.)," Letters in Applied Microbiology, Vol. 42, No.2, 2006, pp. 155-159. http://dx.doi.org/10.1111/j.1472-765X.2005.01827.x

[6] C. B. Jacobson, J. J. Pasternak and B. R. Glick, "Partial Purification and Characterization of 1-Aminocyclopropane1-carboxylate Deaminase from the Plant Growth Promot- 
ing Rhizobacterium Pseudomonas putida GR12-2," Canadian Journal of Microbiology, Vol. 40, No. 12, 1994, pp. 1019-1025. http://dx.doi.org/10.1139/m94-162

[7] B. R. Glick, "The Enhancement of Plant Growth by Free Living Bacteria," Canadian Journal of Microbiology, Vol. 41, No. 2, 1995, pp. 109-114. http://dx.doi.org/10.1139/m95-015

[8] J. Li, D. H. Ovakim, T. C. Charles and B. R. Glick, "An ACC Deaminase Minus Mutant of Enterobacter cloacae UW4 No Longer Promotes Root Elongation," Current Microbiology, Vol. 41, No. 2, 2000, pp. 101-105. http://dx.doi.org/10.1007/s002840010101

[9] D. M. Penrose, B. A. Moffatt and B. R. Glick, "Determination of 1-Aminocyclopropane-1-carboxylic Acid (ACC) to Assess the Effects of ACC Deaminase-Containing Bacteria on Roots of Canola Seedlings," Canadian Journal of Microbiology, Vol. 47, No. 4, 2001, pp. 77-80. http://dx.doi.org/10.1139/w00-128

[10] S. Ghosh, J. N. Penterman, R. D. Little, R. Chavez and B. R. Glick, "Three Newly Isolated Plant Growth-Promoting Bacilli Facilitate the Seedling Growth of Canola Brassica campestris," Plant Physiology and Biochemistry, Vol. 41, No. 3, 2003, pp. 277-281. http://dx.doi.org/10.1016/S0981-9428(03)00019-6

[11] B. Shaharoona, M. Arshad, Z. A. Zahir and A. Khalid, "Performance of Pseudomonas spp. Containing ACCDeaminase for Improving Growth and Yield of Maize (Zea mays L.) in the Presence of Nitrogenous Fertilizer," Soil Biology \& Biochemistry, Vol. 38, No. 9, 2006, pp. 2971-2975. http://dx.doi.org/10.1016/j.soilbio.2006.03.024

[12] B. R. Glick, "Modulation of Plant Ethylene Levels by the Bacterial Enzyme ACC Deaminase," FEMS Microbiology Letters, Vol. 251, No. 1, 2005, pp. 1-7. http://dx.doi.org/10.1016/j.femsle.2005.07.030

[13] M. Honma and T. Shimomura, "Metabolism of 1-Aminocyclopropane-1-carboxylic Acid," Agricultural and Bio- logical Chemistry, Vol. 42, No. 10, 1978, pp. $1825-1831$.

http://dx.doi.org/10.1271/bbb1961.42.1825

[14] G. I. Burd, D. G. Dixon and B. R. Glick, "A Plant Growth-Promoting Bacterium that Decreases Nickel Toxicity in Seedlings," Applied and Environmental Microbiology, Vol. 64, No. 10, 1998, pp. 3663-3668.

[15] C. L. Patten and B. R. Glick, "Bacterial Biosynhesis of Indole-3-Acetic Acid," Canadian Journal of Mirobiology, Vol. 42, No. 3, 1996, pp. 207-220. http://dx.doi.org/10.1139/m96-032

[16] X. F. Sheng and J. J. Xia, "Improvement of Rape (Brassica napus) Plant Growth and Cadmium Uptake by Cadmium-Resistant Bacteria," Chemosphere, Vol. 64, No. 6, 2006, pp. 1036-1042.

http://dx.doi.org/10.1016/j.chemosphere.2006.01.051

[17] S. Zaidi, S. Usmami, B. R. Singh and J. Musarrat, "Significancce of Bacillus subtilis Strain SJ-101 as a Bioinoculant for Concurrent Plant Grown Promotion and Nickel Accumulation in Brassica juncea," Chemosphere, Vol. 64, No. 6, 2006, pp. 991-997. http://dx.doi.org/10.1016/j.chemosphere.2005.12.057

[18] J. M. Bric, R. M. Bostock and S. E. Silversone, "Rapid in Situ Assay for Indole Acetic Acid Production by Bacteria Immobilization on a Nitrocellulose Membrane," Applied and Environmental Microbiology, Vol. 57, No. 2, 1991, pp. 535-538. PMid:16348419 PMCid:PMC182744

[19] M. R. Melo, N. R. Flores, S. V. Murrieta, A. R. Tovar, A. G. Zúñiga, O. F. Hernández, A. P. Mendoza, N. O. Pérez and A. R. Dorantes, "Comparative Plant Growth Promoting Traits and Distribution of Rhizobacteria Associated with Heavy Metals in Contaminated Soils," International Journal of Environmental Science and Technology, Vol. 8, No. 4, 2011, pp. 807-816. http://dx.doi.org/10.1007/BF03326264

[20] D. M. Penrose and B. R. Glick, "Methods for Isolating and Characterizing ACC Deaminase-Containing Plant Growth-Promoting Rhizobacteria," Physiologia Plantarum, Vol. 118, No. 1, 2003, pp. 10-15. http://dx.doi.org/10.1034/j.1399-3054.2003.00086.x

[21] H. Khandelwal and S. S. Sindhu, "Expression of 1-Aminocyclopropane-1-carboxylate Deaminase in Rhizobia Promotes Nodulation and Plant Growth of Clusterbean Cyamopsis tetraganoloba L.)," Research Journal of Microbiology, Vol. 7, No. 3, 2012, pp. 158-170. http://dx.doi.org/10.3923/jm.2012.158.170

[22] M. Dworkin and J. W. Foster, "Experiments with Some Microorganisms Wich Utilize Ethane and Hydrogen," Journal of Bacteriology, Vol. 75, No. 5, 1958, pp. 592601.

[23] A. A. Belimov, N. Hontzeas, V. I. Safronova, S. V. Demchinskaya, G. Piluzza, S. Bullitta and B. R. Glick, "Cadmium-Tolerant Plant Growth-Promoting Bacteria Associated with the Roots of Indian Mustard (Brassica juncea L. Czern.)," Soil Biology \& Biochemistry, Vol. 37, No. 2, 2005, pp. 241-250. http://dx.doi.org/10.1016/i.soilbio.2004.07.033

[24] A. Khalid, M. Arshad and Z. A. Zahir, "Screening Plant Growth-Promoting Rhizobacteria for Improving Growth and Yield of Wheat," Journal of Applied Microbiology, Vol. 96, No. 3, 2004, pp. 473-480. http://dx.doi.org/10.1046/j.1365-2672.2003.02161.x

[25] B. R. Glick, D. M. Karaturovic and P. C. Newell, "A Novel Procedure for Rapid Isolation of Plant Growth Promoting Pseudomonads," Canadian Journal of Microbiology, Vol. 41, No. 6, 1995, pp. 533-536. http://dx.doi.org/10.1139/m95-070

[26] M. L. Evans, H. Ishikawa and M. A. Estelle, "Responses of Arabidopsis Roots to Auxin Studied with High Temporal Resolution: Comparison of Wild Type and AuxinResponse Mutants," Planta, Vol. 194, No. 2, 1994, pp. 215-222. http://dx.doi.org/10.1007/BF01101680

[27] A. Harari, J. Kige and Y. Okon, "Involvement of IAA in the Interaction between Azospirillum brasilense and Panicum miliaceum Roots," Plant and Soil, Vol. 110, No. 2, 1988, pp. 275-282. http://dx.doi.org/10.1007/BF02226808

[28] E. L. Selvadurai, A. E. Brown and J. T. G. Hamilton, 
"Production of Indole-3-Acetic Acid Analogues by Strains of Bacillus cereus in Relation to Their Influence on Seedling Development," Soil Biology \& Biochemistry, Vol. 23, No. 4, 1991, pp. 401-403. http://dx.doi.org/10.1016/0038-0717(91)90198-S

[29] J. E. Loper and M. N. Schroth, "Influence of Bacterial Sources of Indole-3-Acetic Acid on Root Elongation of Sugar Beet," Phytopathology, Vol. 76, No. 4, 1986, pp. 386-389. http://dx.doi.org/10.1094/Phyto-76-386

[30] M. Sawar and R. J. Kremmer, "Enhanced Suppression of Plant Growth through Production of L-Tryptophan Compounds by Deleterious Rhizobacteria," Plant and Soil, Vol. 172, No. 2, 1995, pp. 261-269. http://dx.doi.org/10.1007/BF00011328

[31] H. Xie, J. J. Pasternak and B. R. Glick, "Isolation and Characterization of Mutants of the Plant Growth-Promoting Rhizobacterium Pseudomonas putida GR12-2 that Overproduce Indoleacetic Acid," Current Microbiology, Vol. 32, No. 2, 1996, pp. 67-71. http://dx.doi.org/10.1007/s002849900012

[32] A. A. Belimov, V. I. Safronova, T. A. Sergeyeva, T. N. Egorova, V. A. Matveyeva, V. E. Tsyganov, A. Y. Borisov, I. A. Tikhonovich, C. Kluge, A. Preisfeld, K. J. Dietz and V. V. Stepanok, "Characterisation of Plant Growth-Promoting Rhizobacteria Isolated from Polluted Soils and Containing 1-Aminocyclopropane-1-carboxylate Deaminase," Canadian Journal of Microbiology, Vol. 47, No. 7, 2001, pp. 642-652. http://dx.doi.org/10.1139/w01-062

[33] D. M. Penrose and B. R. Glick, "Levels of 1-Aminocyclopropane-1-carboxylic Acid (ACC) in Exudates and Extracts of Canola Seeds Treated with Plant GrowthPromoting Bacteria," Canadian Journal of Microbiology, Vol. 47, No. 4, 2001, pp. 368-372. http://dx.doi.org/10.1139/w01-014

[34] V. P. Grichko and B. R. Glick, "Amelioration of Flooding Stress by ACC Deaminase Containing Plant GrowthPromoting Bacteria," Plant Physiology and Biochemistry,
Vol. 39, No. 1, 2001, pp. 11-17. http://dx.doi.org/10.1016/S0981-9428(00)01212-2

[35] A. A. Belimov, V. I. Safronova and T. Mimura, "Response of Spring Rape to Inoculation with Plant GrowthPromoting Rhizobacteria Containing 1-Aminocyclopropane-1-carboxylate Deaminase Depends on Nutrient Status of the Plant," Canadian Journal of Microbiology, Vol. 48, No. 3, 2002, pp. 189-199. http://dx.doi.org/10.1139/w02-007

[36] Ch. L. Patten and B. R. Glick, "Role of Pseudomonas putida Indoleacetic Acid in Development of the Host Plant Root System," Applied and Environmental Microbiology, Vol. 68, No. 8, 2002, pp. 3795-3801. http://dx.doi.org/10.1128/AEM.68.8.3795-3801.2002

[37] J. Li and B. R. Glick, "Transcriptional Regulation of the Enterobacter cloacae UW 1-Aminocyclopropane-1-carboxylate (ACC) Deaminase Gene (acdS)," Canadian Journal of Microbiology, Vol. 47, No. 4, 2001, pp. 359367. http://dx.doi.org/10.1139/w01-009

[38] M. Beyerler, P. Michaux, C. Keel and D. Haas, "Effect of Enhanced Production of Indole-3-Acetic Acid by the Biological Control Agent Pseudomonas fluorescens CHA0 on Plant Growth," In: A. Ogoshi, K. Kobayashi, Y. Homma, F. Kodama, N. Kondo and S. Akino, Eds., Plant growth Promoting Rhizobacteria: Present Status and Future Prospects, OECD, Paris, 1997, pp. 310-312.

[39] M. Zafar-Ul-Hye, Z. A. Zahir, S. M. Shahzad, M. Naveed, M. Arshad and M. Khalid, "Preliminary Screening of Rhizobacteria Containing ACC-Deaminase for Promoting Growth of Lentil Seedlings under Axenic Condition," Pakistan Journal of Botany, Vol. 39, No. 5, 2007, pp. 1725-1738.

[40] B. Shaharoona, R. Bibi, M. Arshad, Z. A. Zahir and M. Zia-Ul-Hassan, "1 Aminocyclopropane-1-carboxylate (ACC)-Deaminase Rhizobacteria Extenuates ACC-Induced Classical Triple Response in Etiolated Pea Seedlings," Pakistan Journal of Botany, Vol. 38, No. 5, 2006, pp. 1491-1499. 